\title{
- A Study on Infrastructural Facilities for Differently Abled in Banks \\ IJCRR
}

Section: General Science Sci. Journal Impact Factor 4.016

ICV: 71.54

\section{Archana Singh ${ }^{1}$, U.V. Kiran ${ }^{2}$}

'Research Scholar, School for Home Sciences, Department of Human Development \& Family Studies, Babasaheb Bhimrao Ambedkar University, Lucknow, India; 'Assistant Professor, School for Home Sciences, Department of Human Development \& Family Studies, Babasaheb Bhimrao Ambedkar University, Lucknow, India.

\section{ABSTRACT}

Introduction: Differently abled is a term applied to all persons with disabilities including those having long term physical, intellectual impairment, mental impairments etc. Person with disability often struggle with the complexity of built environment. There are many areas where person with disability face many difficulties of which, bank is one of the main places. This research paper focuses on infrastructural facilities available for differently abled in banks and problems faced by them in bank.

Objective: The present study was taken up to explore the availability of infrastructural facilities for the differently abled and problems faced by them in banks.

Material and Methods: This study adopted a check list method, collected information through observation and questionnaire method from the visitors of the bank. A total of ninety respondents were selected from the Lucknow city irrespective of gender.

Result: The results of this study showed that many banks and ATMs are not physically accessible. There is a general lack of infrastructure and awareness that permits persons with disability to use banking services. ATMs are not equipped to be used by person with disability. Accessible feature and technologies in banks are very low. There are problems for the persons with disability like- lack of ramp and elevators, uncomfortable height of ATMs, etc.

Conclusion: Accessibility for persons with disabilities in banks is very important. Bank should focus on easily available information, bold text explanations etc. which may also include building usable and user friendly voice systems etc.

Key Words: Accessibility, Bank, Differently abled, Infrastructure

\section{INTRODUCTION}

Disability is a part of human condition. Persons with disability face many problems in their daily life. Disability is a complex, dynamic, multidimensional and contested. It is a condition of impairment physical or mental, having an objective aspect that can be usually described by physician (Uromi 2014).

There are many types of disability like- Physical, visual, hearing, speech, and mental disability (Gobalakrishanan 2013). The differently abled face many obstacles in public places, and banks are one such institutions. Where many of the transactions require personal presence and if proper infrastructural facilities for differently are not provided then, it may lead to many hindrance in then day to day life. There is lack of understanding of their needs. Persons with disability face many obstacles when it comes to living a normal life
(Mishra \& Kiran, 2016). It becomes very difficult for differently abled to use public facilities due to lack of accessibility. Lack of ramp which makes impossible for a wheelchair user to use a bank. Uncomfortable height of ATMs which make unwieldy for a wheelchair user to access it are some of the known barriers which generally differently abled face. Barrier free environment makes the differently abled independent and enhance the accessibility to the facilities and services as for a normal person. Hence the present study was taken up to explore the availability of infrastructural facilities for the differently abled and problems faced by them in banks.

\section{Rationale of the study}

India has one of the largest disabled populations in the World. It was estimated that approximately 2.21 percent of India's total population or 2.69 crore are disabled as per census 2011. There are many types of disability like- Physical,

\section{Corresponding Author:}

Archana Singh, Research scholar, School for Home Sciences, Department of Human Development \& Family Studies, Babasaheb Bhimrao Ambedkar University, Lucknow, India; Mob: 9450109729; Email: archanasinghhs@gmail.com

ISSN: 2231-2196 (Print)

Received: 11.05 .2017
ISSN: 0975-5241 (Online)

Revised: 06.06.2017
DOI:

Accepted: 02.07.2017 
visual, hearing, speech, and mental disability. Persons with disabilities face many problems even in doing daily tasks like- walking, hearing, seeing, bending, travelling and moving independently etc.

Special infrastructure is required at public places for making them independent. Bank is one of them, so that they can move easily; enhance their work capacity and their goals. The main purpose of the study is an attempt to explore the facilities provided by our government to provide barrier free environment for persons with disabilities in banks.

\section{BACKGROUND}

Hasanzada M. Taqi (2012), in his study monitored and observed 1725 public buildings including schools, University, government organizations, hospitals, non government buildings in 24 provinces across Afganistan. The result shows that physical accessibility of public places is very difficult.

Banking Services Survey Report (2013). In this survey "Access to Banking Services" found that many disabled face barriers when they use banking services. Disabled person do not get proper access to branches, ATMs etc. But very few disabled people get barrier free facilities in banks.

Basha Rozafa (2015), in her study "Disability and Public Space" focuses to identify the major problems arising from bad planning, design and management of the city. Lack of physical accessibility of public buildings is a main problem. If the public building have ramp before entrance very often their slope is incorrectly designed.

Masood Hajra and Shahla Shabeeh Shaheen (2014) in their study on "Barrier free environment: An analysis of Aligarh city, India", found that barriers make the environment unsafe and cause a high level of difficulty to the user. But more importantly, barriers cause space to be out of reach, denying people the opportunity of participation in various spheres of life.

\section{MATERIALS AND METHODS}

The present study focused on infrastructural facilities available for differently abled in banks and problems faced by them in bank.

In this study, different banks in Lucknow city were selected. Ninety differently abled respondents were selected from Lucknow city, irrespective of gender. In this study a self structured check list was used for exploring the bank facilities as well as the problems faced by people visiting the bank. Simple random sampling and exploratory research design were adopted in the present study.

\section{Statistical methods}

The data was coded, tabulated and analyzed using the PAS software (version 20). The problems faced by differently abled across various categories of disability were analyzed using ANOVA.

\section{RESULTS}

\section{Problems faced by persons with disabilities in banks}

The problems faced by the differently abled in banks are presented in table 1 . The result revealed that majority of the wheelchair users in orthopedically handicapped has problem, as the space inside the bank was very limited and there were lot of restrictions to reach the counter. Access space was very limited and which was the major barrier for $\mathrm{OH}$ to be independent.

Availability and utilization of emergency alarms in bank was very essential to avoid accident/ injuries. The placement of alarm should be in such a place that the normal, as well as differently abled can utilize that service. From the data, it was evident that the hearing impaired had a problem as their audibility was very high and hence could not immediately react to the bells, unless light were fired.

Most of the banks are not provided with proper fire protection controls and it was very important to take note, as it may lead to fire accidents. Almost eighty percent of all categories of differently abled felt that banks were equipped with anti skid flooring.

Almost all the respondents felt that space at entry gate was sufficient and do not create any barrier for entry. Lighting in the banks reported to be sufficient, even the low vision people reported enough lighting in the banks. More percent of the respondents reported that proper seating is available in the banks and available in convenient places.

It may also be noted that more than 95 percent of VI, 90 percent of $\mathrm{OH}$ and 87 percent of $\mathrm{HI}$ reported that non availability of the ramp facility at the entrance, creates obstacles and entry into the bank was very problematic specially for the lower limb amputees or wheel chair users.

It was also reported by the respondents that placement of steps was a common feative among the banks and usually they do not have ramps. Even the banks exiting in the upper floors, were no provided with the ramps but only stair case was available, which creates barriers especially for the differently abled. (Table 1)

\section{General facilities available for persons with disabilities in banks}

General facilities available for persons with disabilities in 
banks are elaborated in table 2. The facilities studied include door width, threshold, entrance landing adjacent to ramp, entrance and exit etc. The dimensions are compared using the standard given by Guidelines and space standards for built environment for disabled and elderly person (Central public works department ministry of urban affairs and employment India 1998) accordingly, the standard width of the entrance door should be $900 \mathrm{~mm}$. all the three banks have door width more than the standards and hence movement through for the differently abled is convenient (bank A- $1524 \mathrm{~mm}$, bank B-1828mm, bank C-1371mm.).

The Entrance landing adjacent to ramp is required, so that the differently abled can reach the entrance easily, but none of the banks has entrance landing. The standard ramp width, maximum length of ramp, height of double handrail, guiding block away from starting and ending of ramp should be $1800 \mathrm{~mm}, 9 \mathrm{~mm}, 800 \mathrm{~mm} * 900 \mathrm{~mm}$, and $300 \mathrm{~mm}$ respectively according to the standard. Without ramp and guiding blocks in the banks differently abled specially wheelchair users and visually impaired people cannot reach the bank easily. Wheelchair users cannot enter in the bank without ramp.

The width of the stairs is also one of the prominent factor and in selected banks, it was found that the bank B had appropriate width of stairs, and bank $\mathrm{A}$ and $\mathrm{C}$ were bigger than the standard width. Where the standard stair width should be $1350 \mathrm{~mm}$. The standard height of riser should be $150 \mathrm{~mm}$ and surveyed in surveyed banks, it was found that in bank A $(152 \mathrm{~mm})$, in bank B $(203 \mathrm{~mm})$ the height of the riser is more than the standard height. Hence differently abled face problem in climb the stairs. The standard width of the tread should be $300 \mathrm{~mm}$. and in bank A, tread width is lesser than the standard, so differently abled cannot put their feet properly. Where as in bank B, it was according to the standard and hence comfortable. Bank C, it is $762 \mathrm{~mm}$, bigger than the standard. The standard extension of handrail should be 300 $\mathrm{mm}$, but was found to be missing in all the surveyed banks and without extension of handrail climbing the stairs is very difficult for differently abled and is quiet accident prone.

The standard height of handrail should be $800 \mathrm{~mm} \& 900$ $\mathrm{mm}$, in bank B it is $1219 \mathrm{~mm}$, bank C it is found to be 914 $\mathrm{mm}$. The height of handrail is more in bank $\mathrm{B}$ and $\mathrm{C}$ than standard and it poses problem for the differently abled in climbing the staircase. One of the banks do not have handrail at all and is quiet accident prone.

The standard Counter height in banks should be $700 \mathrm{~mm}$. In all the banks, the counter height was not found according to standards (bank-A $1524 \mathrm{~mm}$, bank-B 1066mm, bank-C $2133 \mathrm{~mm}$.) The counter height was not convenient for differently abled because of the excessive height of the counter. The standard depth under the counter should be $350 \mathrm{~mm}$. In bank A, it was found that the depth of counter is $254 \mathrm{~mm}$, and it was not according to the standard, and hence differently abled cannot use the counter properly. In bank B, it was 381 $\mathrm{mm}$; it was found to be convenient for differently abled and bank $\mathrm{C}$ the counter depth was found to be $177.8 \mathrm{~mm}$. It was less than the standard depth and hence differently abled cannot use it conveniently.

The height of placement of switches from the finished floor should be $900-1200 \mathrm{~mm}$., but no banks has followed the standards and the switches are placed at a height, where the wheelchair users cannot use them at all. The opening controls of windows and doors were also not found to be as per standard $(1400 \mathrm{~mm}$ from the finished floor), and hence the wheelchair users cannot comfortably control the openings. (bank- A 2133mm, bank C- 1828mm.). (Table 2)

\section{DISCUSSION}

This research paper highlights many problems faced by differently abled when they use banking. Physical accessibility is found to be the major problem in banks, if the bank building is not provided with enough ramp and clear entrance. Visually impaired often face lot of problems while using ATMs, because the keys are not in Braille. ATMs are not at proper height and hence standing up wheelchair users cannot see the ATM screen. These barriers create difficulties for differently abled. Accessible features and technologies in banks are very low. Wheelchair users cannot access the bank easily. They cannot open the door and access the counter, because counters very high. So the banks should improve their physical accessibility for differently abled. Though the banks are mandated to ensure there is accessibility in banks, but there is still a lot that needs to be done. There are several measures that can be taken up by banks, which will not be costly and which will be especially rewarding for differently abled. For the mobility they have to profoundly rely on the other people. Offices be made more accessible and prepared with assistive aids such as wheelchairs, handrails and facilities such as ramps, stairs with double handrail, sufficient space at entry gate, separate counter for differently abled etc. Special measures should be adopted for providing specific provisions for wheelchair users, such as a selected queue and teller, so that they do not have to wait in queue for a long period of time.

\section{CONCLUSION}

This study has clearly demonstrated that there are many problems for persons with disabilities in banks. Persons with disabilities cannot use banking services properly. The respondents reported many problems in banks like- no sufficient space for wheelchair users, no separate counter for persons with disability. No availability of ramp and emergency alarms etc. On the other hand, result indicates that lack of infrastructural facilities of bank as per the standard is found to 
be the major problem for persons with disabilities. Physical access in banks faces major problem for the users and hence the availability of ramp, wider lift, guiding blocks, ATMs at proper height, handrails etc. in banks should be concentrated to enhance the accessibility of differently abled users.

\section{ACKNOWLEDGEMENT}

Authors acknowledge the immense help received from the scholars whose articles are cited and included in references of this manuscript. The authors are also grateful to authors / editors / publishers of all those articles, journals and books from where the literature for this article has been reviewed and discussed.

\section{Source of Funding-}

I have been receiving University fellowship for this program.

\section{Abbreviations}

$\mathrm{OH}$

Orthopedically handicapped

VI

Visually impaired

HI

Hearing impaired

ATM

Automated Teller Machine

PAS

Power Analysis Software

\section{REFERENCES}

1. Access to Banking Services Survey Report( 2013) .available at http://www.dpa.org.sg/wp-content/uploads/2013/04/SurveyReport.pdf. /Accessed on February 2017.

2. Banking and Accessibility in India: A Study on Banking Accessibility in India (2013). Available at http://cis-india.org/accessibility/blog/banking-accessibility.pdf Accessed on February 2017.

3. Basha Rozafa (2015), "Disability and Public Space-Case Studies of Prishtina and Prizren", International Journal of Contemporary Architecture, 2015, vol.2 no. 3,54-66.

4. Gobalakrishanan, C. (2013). "Problem faced by physically challenged persons and their awareness towards welfare measures", International journal of innovative research \& development, 2013, vol.2 no4,487-493.

5. Guidelines and space standards for built environment for disabled and elderly person ( Central public works department ministry of urban affairs and employment India 1998) http://cpwd. gov.in Accessed on February 2017.

6. Hasanzada, M. Taqi (2012), "Physical accessibility of persons with disabilities to public places". In Afghanistan independent human rights commission. http://www.aihrc.org.af/ Accessed on March 2017.

7. Mishra Garima and Kiran, U.V. (2016), "Barrier in using ICT devices among visually impaired students" International journal of research in social sciences, 2016,vol. 6, issue 9, 569-587.

8. Masood Hajra and Shahla Shabeeh Shaheen. (2014). "Barrier free environment: An analysis of Aligarh City, India.in International journal of interdisciplinary and studies, 2014, Vol.1, no 9, 8-15.

9. Uromi M.Sabbath and Mazagwa Iboku (2014). "Challenges facing people with disabilities and possible solutions in Tanzania", Journal of education policy and entrepreneurial research (2014), Vol 1, no.2, 158-165.

Table 1: Problems faced by persons with disabilities in banks

\begin{tabular}{|c|c|c|c|c|c|c|}
\hline S. no. & General Facilities & $\begin{array}{c}\mathrm{OH} \\
\text { Mean } \pm \mathrm{SD}\end{array}$ & $\begin{array}{c}\text { VI } \\
\text { Mean } \pm \text { SD }\end{array}$ & $\begin{array}{c}\text { HI } \\
\text { Mean }+ \text { SD }\end{array}$ & F value & Pvalue \\
\hline 1. & Sufficient space for wheelchair users & $0.90 \pm 0.30$ & $0.77 \pm 0.43$ & $0.93 \pm 0.25$ & 2.04 & 0.13 \\
\hline 2. & Emergency alarm are available & $0.83 \pm 0.37$ & $0.30 \pm 0.46$ & $0.93 \pm 0.25$ & $24 \cdot 53$ & 0.00 \\
\hline 3. & $\begin{array}{l}\text { Fire protection and controls are } \\
\text { available }\end{array}$ & $0.97 \pm 0.18$ & $0.23 \pm 0.43$ & $0.90 \pm 0.30$ & $47 \cdot 51$ & 0.00 \\
\hline 4. & $\begin{array}{l}\text { Floors are finished by anti-skid } \\
\text { material }\end{array}$ & $0.83 \pm 0.37$ & $0.77 \pm 0.43$ & $0.80 \pm 0.40$ & 0.20 & 0.81 \\
\hline 5. & $\begin{array}{l}\text { Sufficient space is available at entry } \\
\text { gate }\end{array}$ & $0.83 \pm 0.37$ & $1.00 \pm 0.00$ & $0.63 \pm 0.49$ & $7 \cdot 90$ & 0.01 \\
\hline 6. & Banks are well enlighted & $0.90 \pm 0.31$ & $0.20 \pm 0.40$ & $0.87 \pm 0.34$ & 36.28 & 0.00 \\
\hline 7. & $\begin{array}{l}\text { Banks are well enlighted for low vi- } \\
\text { sion people }\end{array}$ & $0.80 \pm 0.40$ & $0.80 \pm 0.40$ & $0.90 \pm 0.30$ & 0.70 & 0.49 \\
\hline 8. & $\begin{array}{l}\text { Seats are placed in proper and con- } \\
\text { venient places }\end{array}$ & $0.87 \pm 0.34$ & $1.00 \pm 0.00$ & $0.93 \pm 0.25$ & 2.17 & 0.12 \\
\hline 9 . & Separate counter for disabled & $0.27 \pm 0.45$ & $0.07 \pm 0.25$ & $0.43 \pm 0.50$ & 5.82 & 0.04 \\
\hline 10. & $\begin{array}{l}\text { Availability of ramps with durable } \\
\text { anti-skid surface }\end{array}$ & $0.90 \pm 0.46$ & $0.95 \pm 0.49$ & $0.87 \pm 0.34$ & 2.79 & 0.06 \\
\hline 11. & $\begin{array}{l}\text { Inclusion of stairs with properly de- } \\
\text { signed handrails together with ramps }\end{array}$ & $0.77 \pm 0.43$ & $0.73 \pm 0.45$ & $0.77 \pm 0.43$ & 0.05 & 0.94 \\
\hline
\end{tabular}


Table 2: General facilities available for persons with disabilities in banks

\begin{tabular}{|c|c|c|c|c|c|}
\hline \multirow[t]{2}{*}{ S.No. } & & $\begin{array}{l}\text { *Standard (Measure- } \\
\text { ment of public places) }\end{array}$ & Existing & & \\
\hline & & & Bank & & \\
\hline $\mathbf{A}$ & Entrance/exit & & $\mathbf{A}$ & B & $\mathrm{C}$ \\
\hline 1 & Door width & 900 mm (3 feet) & $1524 \mathrm{~mm}$ ( 5 feet $)$ & $1828 \mathrm{~mm}$ ( 6 feet) & $1371 \mathrm{~mm}(41 / 2$ feet \\
\hline
\end{tabular}

2 Entrance landing adjacent $1800 \mathrm{~mm}^{*} 2000 \mathrm{~mm}$ to ramp

B Ramp

$1 \quad$ Ramp width

2 Maximum length of ramp

3 Height of double handrail

4 Guiding block away from starting and ending of ramp

C Stair

$1 \quad$ Minimum width

2 Height of riser

3 Width of the tread

$4 \quad$ Extension of handrail

5 Height of handrail

D Counter

1 Counter height

$700 \mathrm{~mm}\left(2^{1 / 2}\right.$ feet $)$

$800 \mathrm{~mm} \& 900 \mathrm{~mm}\left(2^{1 / 2} \&\right.$ 3 feet)

$800 \mathrm{~mm}$ * $900 \mathrm{~mm}$

$300 \mathrm{~mm}$ (1 feet)

$1350 \mathrm{~mm}\left(4^{1 / 2}\right.$ feet $)$

$150 \mathrm{~mm}\left(5^{\prime \prime}\right)$

$300 \mathrm{~mm}$ (1 feet)

$152 \mathrm{~mm}(1 / 2$ feet $)$

$300 \mathrm{~mm}$ (1 feet)

$762 \mathrm{~mm}\left(2^{1 / 2}\right.$ feet $)$

Ramp was not available

$1828 \mathrm{~mm}$ (6 feet) $914 \mathrm{~mm}$ (3 feet) $2438 \mathrm{~mm}$ (8 feet)

$152 \mathrm{~mm}(6 ”) \quad 203 \mathrm{~mm}\left(8^{\prime \prime}\right)$

$101 \mathrm{~mm}(4 ”)$

$300 \mathrm{~mm}$ (1 feet)

$1524 \mathrm{~mm}$ ( 5 feet)

$1066 \mathrm{~mm}(31 / 2$

feet)

$1219 \mathrm{~mm}$ (4 feet) $914 \mathrm{~mm}$ (3 feet)

2 Depth under the counter

$350 \mathrm{~mm}(14 ")$

$254 \mathrm{~mm}(10 ")$

$381 \mathrm{~mm}(15)$

$177.8 \mathrm{~mm}\left(7^{\prime \prime}\right)$

$2133 \mathrm{~mm}$ (7 feet) $1219 \mathrm{~mm}$ ( 4 feet) $\quad 1828 \mathrm{~mm}$ ( 6 feet $)$

E Controls

1 Switches from the finished $900 \mathrm{~mm}-1200 \mathrm{~mm}$ floor

2 Opening controls of window $1400 \mathrm{~mm}$ (4.6 feet) and doors from the finish floor

* Guidelines and space standards for built environment for disabled and elderly person ( Central public works department ministry of urban affairs and employment India 1998) 


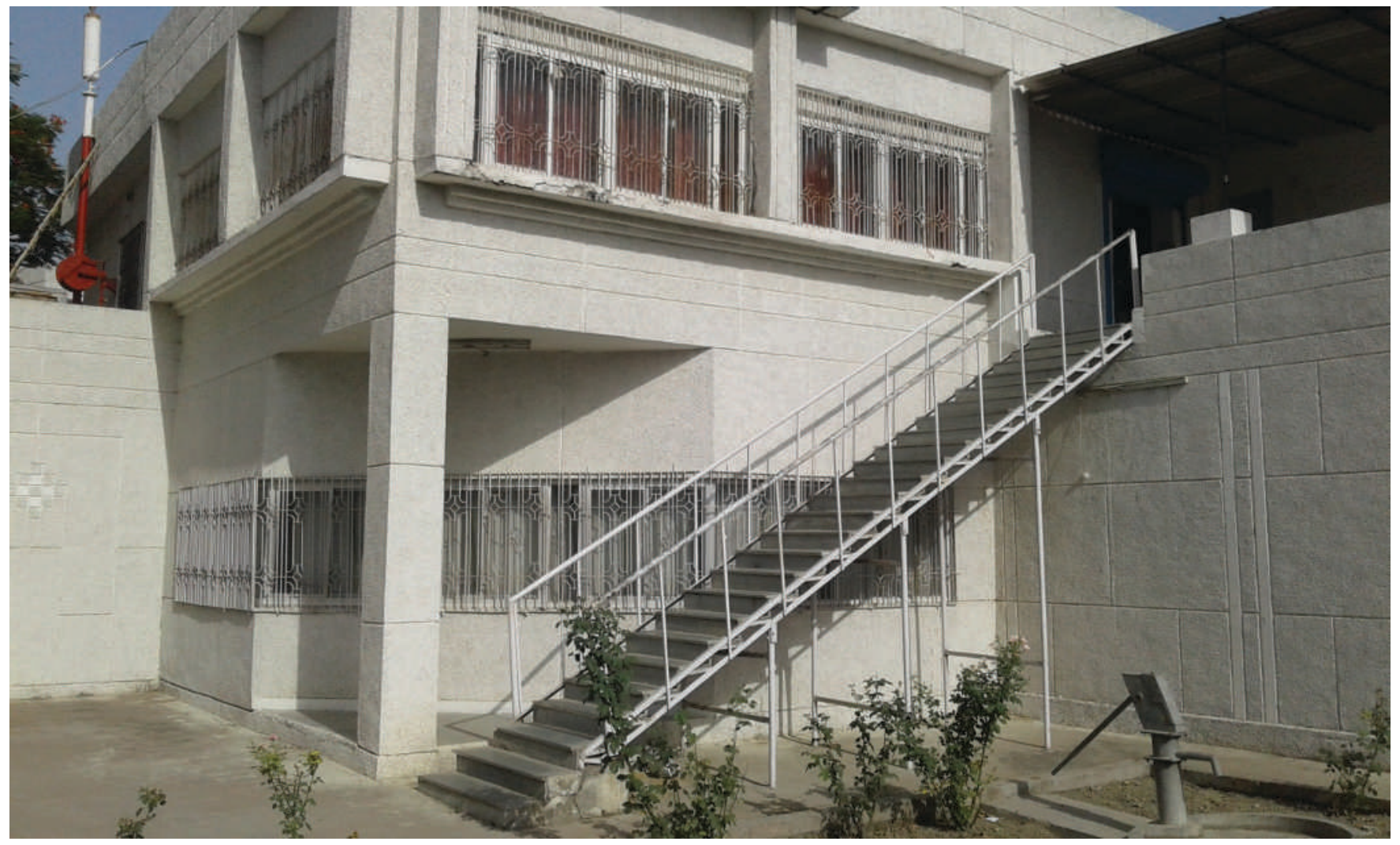

Figure 1: Prospective view of the bank where there is no ramp facility. 